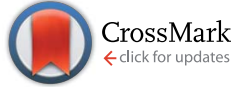

Cite this: RSC Adv., 2017, 7, 7170

Received 10th November 2016 Accepted 12th January 2017

DOI: $10.1039 / c 6 r a 26614 b$

www.rsc.org/advances

\section{Selenium supplementation can protect from enhanced risk of keel bone damage in laying hens exposed to cadmium}

\author{
Runxiang Zhang, ${ }^{a}$ Lu Xing, ${ }^{b}$ Jun Bao, ${ }^{a}$ Hanqing Sun, ${ }^{a}$ Yanju Bi, ${ }^{a}$ Huo Liu ${ }^{b}$ \\ and Jianhong $\mathrm{Li}^{* \mathrm{~b}}$
}

The aim of this study was to investigate whether selenium (Se) supplementation can provide protection from an enhanced risk of keel bone damage (KBD) in laying hens due to the cadmium (Cd) toxicity associated with sub-chronic exposure. In this trial, based on the model of laying hens fed a diet supplemented with $\mathrm{Se}, \mathrm{Cd}$ or $\mathrm{Se}+\mathrm{Cd}$ in combination, the keel bone fractures and deviations, the bone mineral density (BMD), the serum biomarkers and the levels of twenty-eight elements were investigated. Consumption of feed added $150 \mathrm{mg} \mathrm{kg}^{-1} \mathrm{CdCl}_{2}$ had a significant adverse effect on the keel bone, as determined by an increase in the percentage of keel bone damage, and a decrease in the BMD and the serum osteocalcin $(\mathrm{OC})$. Supplementation with $\mathrm{Cd}$ led to disorders of mineral element metabolisms, including reduced concentrations of $\mathrm{Si}, \mathrm{K}, \mathrm{Ca}, \mathrm{Cr}, \mathrm{Mn}, \mathrm{Cu}, \mathrm{Zn}$ and $\mathrm{Mo}$, and increased concentrations of $\mathrm{Cd}$, and $\mathrm{Pb}(P<0.05)$. Supplementation with $2 \mathrm{mg} \mathrm{kg}^{-1} \mathrm{Na}_{2} \mathrm{SeO}_{3}$ reduced keel bone damage, as well as the concentrations of toxic microelements $\mathrm{Al}$ and $\mathrm{Pb}$. Se supplementation during 13 weeks of exposure to $\mathrm{Cd}$ partially prevented $\mathrm{Cd}$-induced increase rates of the keel bone fracture and decrease concentrations of $\mathrm{OC}$. Moreover, the $\mathrm{Se}+\mathrm{Cd}$ co-treatment alleviated the degree of changes in $\mathrm{K}, \mathrm{Ca}$, $\mathrm{Cr}, \mathrm{Cu}, \mathrm{Zn}, \mathrm{Cd}$ and $\mathrm{Pb}$ concentrations which in contrast were induced by $\mathrm{Cd}(P<0.05)$. These results support the conclusion that enhanced Se supplementation during sub-chronic $\mathrm{Cd}$ exposure can, at least partially, reduce keel bone damage. This protective effect may result from maintenance of homeostasis of the elements in bones of laying hens.

\section{Introduction}

Cadmium (Cd) is known to be a widespread industrial and environmental contaminant endangering human and animal health. ${ }^{\mathbf{1}}$ It can be absorbed from water, food, and air pollutants, and upon exposure, Cd accumulates in liver, kidney, brain, bone and other tissues, with a long biological half-life in the body. ${ }^{2,3}$ Bone is one of the critical target organs affected by $\mathrm{Cd}$ exposure. Many reports have demonstrated an adverse effect of $\mathrm{Cd}$ on bone health, characterized by decreased mineralization and increased prevalence of fractures. ${ }^{4-6} \mathrm{Cd}$ toxicity has been linked to abnormal metabolism of bone cells and a disruption of the absorption and excretion of calcium (Ca) in the intestines and kidneys; this leads to a deficiency in Ca levels and, consequently, the bone damage. ${ }^{7,8}$ Homeostasis of mineral elements plays vital roles in metabolic diseases of nutrition and toxipathy. ${ }^{\mathbf{9} 10}$ Many studies have demonstrated that the essential metals, such as $\mathrm{Ca}$, magnesium $(\mathrm{Mg})$, zinc $(\mathrm{Zn})$, and copper $(\mathrm{Cu})$

${ }^{a}$ College of Animal Science and Technology, Northeast Agricultural University, Harbin 150030, People's Republic of China

${ }^{b}$ College of Life Science, Northeast Agricultural University, Harbin, 150030, People's Republic of China. E-mail: jhlineau@126.com are necessary for bone health and are susceptible to the toxic effects of Cd. ${ }^{\mathbf{1 1 - 1 5}}$ Brzoska et al. demonstrated that $5 \mathrm{mg} \mathrm{Cd} / \mathrm{L}$ added to the water decreased the $\mathrm{Ca}$, phosphate (P) and $\mathrm{Zn}$ concentrations, whereas a $50 \mathrm{mg} \mathrm{Cd} / \mathrm{L}$ dosage decreased the $\mathrm{Ca}$, $\mathrm{P}, \mathrm{Zn}, \mathrm{Mg}, \mathrm{Cu}$ and iron (Fe) contents in lumbar vertebral, and the bone mineral density (BMD) was decreased. ${ }^{16}$ The same group also discovered that low chronic exposure to $\mathrm{Cd}\left(1 \mathrm{mg} \mathrm{\textrm {L } ^ { - 1 }}\right.$ in drinking water for 24 months) decreased the femur and tibia levels of $\mathrm{Ca}, \mathrm{Mg}, \mathrm{Zn}, \mathrm{Cu}$ and $\mathrm{Fe}$, which enhanced bone fracture risks. ${ }^{17}$ However, the effects of $\mathrm{Cd}$ on the minerals of bones and the bone damage of laying hens are most unknown.

Selenium (Se) is an essential trace element with antioxidant, antimutagenic, and anticarcinogenic properties for the body. ${ }^{18,19}$ In the form of antioxidant selenoprotein, such as glutathione peroxidase (GPx) and thioredoxin reductase (TrxR), Se has beneficial effects on maintaining bone homeostasis and protecting against bone loss. ${ }^{20,21}$ In previous studies, Se supplementation with dietary $\mathrm{Cd}$ has alleviated $\mathrm{Cd}$ toxicity and markedly reduced $\mathrm{Cd}$ accumulation in brain, liver and kidney. ${ }^{22,23}$ However, Al-Waeli et al. has indicated that addition of dietary Se did not significantly reduce Cd concentrations in the broilers' tissues. ${ }^{24}$ This result is inconsistent with other reports wherein se was added to chicken diets from 0.15 up to 
$3 \mathrm{mg} \mathrm{kg}^{-1}$, reducing $\mathrm{Cd}$ deposition, and Se was positively correlated with $\mathrm{Zn}, \mathrm{Cu}$ and $\mathrm{Fe}^{25}$ In our previous study, $\mathrm{Cd}$ supplementation of the chicken diet caused ion profile disorders in kidney, including drastic increases or decreases in thirteen mineral elements, and supplementation with Se increased the levels of chromium (Cr), manganese ( $\mathrm{Mn}), \mathrm{Zn}$, and $\mathrm{Se}$, and decreased lithium $(\mathrm{Li})$ and lead $(\mathrm{Pb})$, which in contrast were induced by $\mathrm{Cd}^{26}{ }^{26}$ While it has been well established that levels of multiple elements are simultaneously altered, the interplay between these elements and indicators of bone damage under the effects of Se or Cd individually or combined, have yet to be studies.

Keel bone damage (KBD), including fractures and deviations to the keel bone, is one of the major welfare and health issues in commercial laying hens..$^{27,28}$ The high incidence of keel fractures in cages could result from calcium deficiency or other nutritional disorders. ${ }^{29}$ The occurrence of KBD is accompanied with age and dramatically increased at the peak of lay, resulting from bones that are weakened by the process of demineralization. ${ }^{30}$ Therefore, based on the model of laying hens fed diets supplemented with $\mathrm{Se}$, Cd or both in combination, we have detected KBD, BMD, serum alkaline phosphatase (ALP) activity, concentrations of osteocalcin (OC) and levels of twenty-eight elements in the keel bone of laying hens. The aim of this study was to investigate whether the addition of Se could provide protection from the toxic effects of $\mathrm{Cd}$ on keel bone health in laying hens.

\section{Materials and methods}

\section{Birds and protocol}

A total of Ninety six Hy-Line brown laying hens at 31 weeks of age were randomly divided into four experimental groups according to dietary treatments. In each experimental treatment, there were eight replicate cages, each with three laying hens. The hens were fed a commercial basic diet containing a metabolizable energy of $11.13 \mathrm{MJ} \mathrm{kg}^{-1}$ and $16.08 \%$ crude protein. The basic diet contained $0.2 \mathrm{mg} \mathrm{kg}^{-1} \mathrm{Se}$ and $0.08 \mathrm{mg}$ $\mathrm{kg}^{-1} \mathrm{Cd}$, which was fed to control birds. The Se, Cd or Se + Cd supplemented feeds were prepared according to our previous reports. ${ }^{31}$ Briefly, in the Se treated group, hens were fed a basic diet supplemented with $2 \mathrm{mg} \mathrm{kg}^{-1}$ of $\mathrm{Na}_{2} \mathrm{SeO}_{3}$, to yield doses of $0.91 \mathrm{mg} \mathrm{kg}^{-1} \mathrm{Se}$. This was accomplished by preparing a solution of $2 \mathrm{~g} \mathrm{~L}^{-1} \mathrm{Na}_{2} \mathrm{SeO}_{3}$ in distilled water, and adding an appropriate volume of $100 \mathrm{~mL}$ solute $\mathrm{Na}_{2} \mathrm{SeO}_{3}$ to $100 \mathrm{~kg}$ of the basic diet, and thoroughly mixing in a mixer. In the Cd treated group, chickens were fed a basic diet with an addition of $150 \mathrm{mg} \mathrm{kg}^{-1} \mathrm{CdCl}_{2}$ to yield levels of $91.98 \mathrm{mg} \mathrm{kg}{ }^{-1} \mathrm{Cd}$. The supplement feeds were prepared by adding $100 \mathrm{~mL}$ of distilled water containing a solution of $150 \mathrm{~g} \mathrm{~L}^{-1} \mathrm{CdCl}_{2}$ to $100 \mathrm{~kg}$ feed, and thoroughly mixed as previously described. For the $\mathrm{Se}+\mathrm{Cd}$ treated group, hens were fed a basic diet supplemented with $2 \mathrm{mg} \mathrm{kg}{ }^{-1}$ of $\mathrm{Na}_{2} \mathrm{SeO}_{3}$ and $150 \mathrm{mg} \mathrm{kg}{ }^{-1}$ of $\mathrm{CdCl}_{2}$. This was accomplished by making a perfect mixing with the equal mixture of $\mathrm{CdCl}_{2}$ supplemented feeds and $\mathrm{Na}_{2} \mathrm{SeO}_{3}$ supplemented feeds. Chickens were fed their respective diets for a period of 13 weeks. Laying hens were housed in an environmentally controlled room and received identical standard management. The temperature was maintained at 18$23{ }^{\circ} \mathrm{C}$ and a lighting cycle of $16 \mathrm{~h}$ of light and $8 \mathrm{~h}$ of dark. All hens were given ad libitum access to feed and water. The contents of $\mathrm{Se}, \mathrm{Cd}$, and twenty-six other elements in the basic diet and water are shown in Table 1. All experiments were approved by and conducted according to the guidelines of the Institutional Animal Care and Use Committee of Northeast Agriculture University.

\section{Assessment of keel bone damage}

To assess KBD, sixteen hens per treatment (two random selected hens in each cage) were palpated by the same investigator at the initiation of the study (31 weeks of age) and at study termination (44 weeks of age). Palpations were performed by running two fingers down the edge of the keel bone, feeling for alterations such as S-derivations, bumps or depressions, all indicators of keel bone damage..$^{32}$ Fractures and deviations were assessed using a scoring scheme adapted from Scholz et al. ${ }^{33}$ The scores were condensed into three categories; normal keel bone (NK), deviated keel bone (DK) with the deviation of the keel from a theoretical two-dimensional straight plane in either the transverse or median sagittal planes ${ }^{34}$ and fractured keel bone (FK), with the presence of sharp edges, clear displacements or shearing and bumps. ${ }^{34}$ If a keel bone had both of a fracture and a deviation, the laying hens was assigned FK according to the fractures were more likely to be related to pain

Table 1 Contents of Se, Cd and other 26 elements in the basic diet and drinking water

\begin{tabular}{lrr}
\hline Elements & Hens feed $\left(\mathrm{mg} \mathrm{kg}^{-1}\right)$ & Tap water $\left(\mu \mathrm{g} \mathrm{L}^{-1}\right)$ \\
\hline $\mathrm{Li}$ & 1.09 & \\
$\mathrm{~B}$ & 6.02 & 1.65 \\
$\mathrm{Na}$ & 1160.55 & 6.07 \\
$\mathrm{Mg}$ & 2222.08 & 1174.35 \\
$\mathrm{Al}$ & 203.59 & 22.55 \\
$\mathrm{Si}$ & 4019.03 & 1533.88 \\
$\mathrm{~K}$ & 8158.82 & 1323.22 \\
$\mathrm{Ca}$ & 61.83 & 7062.40 \\
$\mathrm{Ti}$ & 26.60 & 4.67 \\
$\mathrm{~V}$ & 2.10 & 0.19 \\
$\mathrm{Cr}$ & 2.24 & 0.13 \\
$\mathrm{Mn}$ & 139.10 & 2.88 \\
$\mathrm{Fe}$ & 90.64 & 12.03 \\
$\mathrm{Co}$ & 1.05 & 0.07 \\
$\mathrm{Ni}$ & 6.72 & 7.84 \\
$\mathrm{Cu}$ & 24.83 & 64.67 \\
$\mathrm{Zn}$ & 147.42 & 304.54 \\
$\mathrm{As}$ & 0.34 & 0.65 \\
$\mathrm{Se}$ & 0.20 & 0.17 \\
$\mathrm{Sr}$ & 5.06 & 48.45 \\
$\mathrm{Mo}$ & 1.62 & 0.34 \\
$\mathrm{Cd}$ & 0.08 & 0.07 \\
$\mathrm{Sn}$ & 1.15 & 0.16 \\
$\mathrm{Sb}$ & 0.06 & 0.08 \\
$\mathrm{Ba}$ & 3.03 & 0.02 \\
$\mathrm{Hg}$ & 0.01 & 0.01 \\
$\mathrm{Tl}$ & 0.02 & 1.42 \\
$\mathrm{~Pb}$ & 0.45 &
\end{tabular}


than deviation. ${ }^{33}$ At the end of the experiment, palpated chickens were euthanized by cervical dislocation and the keel bones were removed and cleaned of excess flesh. The keel bones were examined visually to confirm the presence or absence of fractures and deviations using the same scoring system for comparison with palpation data collected from the same chickens. Each keel bone was then wrapped in a piece of gauze saturated with an isotonic saline solution and stored in separate plastic zip-lock bags at $-20{ }^{\circ} \mathrm{C}$ for further analysis.

\section{Measurement of keel BMD}

Half of the collected keel bones (eight per treatment) were thawed. BMD of keel bones were measured using computerized radiographic densitometry with a veterinary X-ray unit RV-500 (58 kV, R-TEC Corporation, Fukuura, Yokohama, Japan). Briefly, the keel bones were blotted and side placed on a $25.2 \times$ $33 \mathrm{~cm}$ X-ray plate and a step standard scale with $0.25 \mathrm{~mm}$ increment aluminum step wedge was also placed on the plate at the same time used as a standard. Images were collected and analyzed using ImageJ software (National Institute of Health, Bethesda, MD, USA). ${ }^{35}$ The ImageJ program calibrated mean radiographic density of each keel bone in terms of $\mathrm{mm}$ of aluminum equivalence.

\section{Measurement of serum ALP and OC}

Before the hens were slaughtered, serum was collected and stored at $-20{ }^{\circ} \mathrm{C}$ prior to analysis. ALP activity was measured with an automatic biochemistry analyzer (Hitachi 7600-020, Hitachi Ltd., Tokyo, Japan) using the accompanying commercial ALP kits.

Serum OC concentrations were quantified using commercially available ELISA tests (Shanghai jinma laboratory equipment Corporation., Ltd, Shanghai, China) following the manufacturer's instructions. Optical densities (OD) were measured at a wavelength of $450 \mathrm{~nm}$ by microplate reader (Biotek Instrument Inc. USA). A standard curve was prepared with the following concentrations: $30,60,120,240$ and $480 \mathrm{ng} \mathrm{L}^{-1}$, and to produce a linear equation for quantification of experimental samples.

\section{Determination of bone elements}

A sample of each collected keel bones (eight keel bones per treatment) were completely digested with a microwave digestion system. Twenty-eight mineral elements [including those of $\mathrm{Li}$, boron (B), sodium (Na), Mg, aluminum (Al), silicon ( $\mathrm{Si}$ ), potassium (K), Ca, titanium (Ti), vanadium (V), Cr, Mn, Fe, cobalt (Co), nickel (Ni), Cu, Zn, arsenic (As), Se, strontium ( $\mathrm{Sr}$ ), molybdenum (Mo), Cd, tin (Sn), antimony (Sb), barium (Ba), mercury $(\mathrm{Hg})$, thallium $(\mathrm{Tl})$, and $\mathrm{Pb}$ ] from bone tissues, serum, basic diet and water were determined using inductively coupled plasma mass spectrometry, ICP-MS (Thermo iCAP Q, MA, USA) ${ }^{26}$ Briefly, $1.0 \mathrm{~g}$ or $0.5 \mathrm{~mL}$ of each sample was performed digestion in a solution of $5 \mathrm{~mL} 65 \%(\mathrm{w} / \mathrm{w}) \mathrm{HNO}_{3}$ and $2 \mathrm{~mL} 30 \%$ $\mathrm{H}_{2} \mathrm{O}_{2}$ (w/v), then diluted to a final volume of $10 \mathrm{~mL}$ with deionized water. Samples were heated in a microwaveaccelerated digestion system with the following heating program: (1) ramped up to $1800 \mathrm{~W}$ for $10 \mathrm{~min}$, (2) $3 \mathrm{~min}$ at $100{ }^{\circ} \mathrm{C}$, (3) $10 \mathrm{~min}$ at $150{ }^{\circ} \mathrm{C}$, and (4) $45 \mathrm{~min}$ at $180{ }^{\circ} \mathrm{C}$. After cooling to room temperature, the digested samples were diluted with Milli-Q water to a final volume of $50 \mathrm{~mL}$ and mixed well prior to ICP-MS analysis. All analyses were carried out according to the manufacturer's instructions. The operating conditions were as follows: frequency $27.12 \mathrm{MHz}$, RF power $1550 \mathrm{~W}$, carrier gas flow rate $1.05 \mathrm{~L} \mathrm{~min}^{-1}$, plasma gas flow rate $14.0 \mathrm{~L} \mathrm{~min}^{-1}$, auxiliary gas flow rate $0.8 \mathrm{~L} \mathrm{~min}^{-1}$, spray chamber temperature $2.7{ }^{\circ} \mathrm{C}$, sampling depth $6.0 \mathrm{~mm}$, nebulizer pump $40 \mathrm{rpm}$. All samples were analyzed in batches with blanks and known standards.

\section{Statistical analysis}

The data analysis was performed using SPSS for Windows (SPSS Inc., Chicago, IL, USA) and GraphPad Prism 5.01 (GraphPad Inc., La Jolla, CA, USA). Differences between treated groups were analyzed by one-way ANOVA followed by the Tukey honest significant difference test. A probability value of $P<0.05$ was considered statistically significant. All data showed a normal distribution, and passed equal variance testing. Data were expressed as the mean \pm standard deviation. Correlations between elements were investigated using Spearman's correlation test. Values $>0.50$ were taken as an indication of a strong correlation.

\section{Results}

\section{Keel bone damage and radiography density}

The results of keel bone fractures and deviations of laying hens are showed in Fig. 1. At the initiation of the study, the number of laying hens with normal keel bones is the same among four groups. The percentages of FK and DK in control group, Se treated group, $\mathrm{Se}+\mathrm{Cd}$ treated group and $\mathrm{Cd}$ treated group were $6.25 \%$ and $12.5 \%, 0 \%$ and $18.75 \%, 6.25 \%$ and $12.5 \%, 0 \%$ and $18.75 \%$, respectively. At study termination, the percentages of

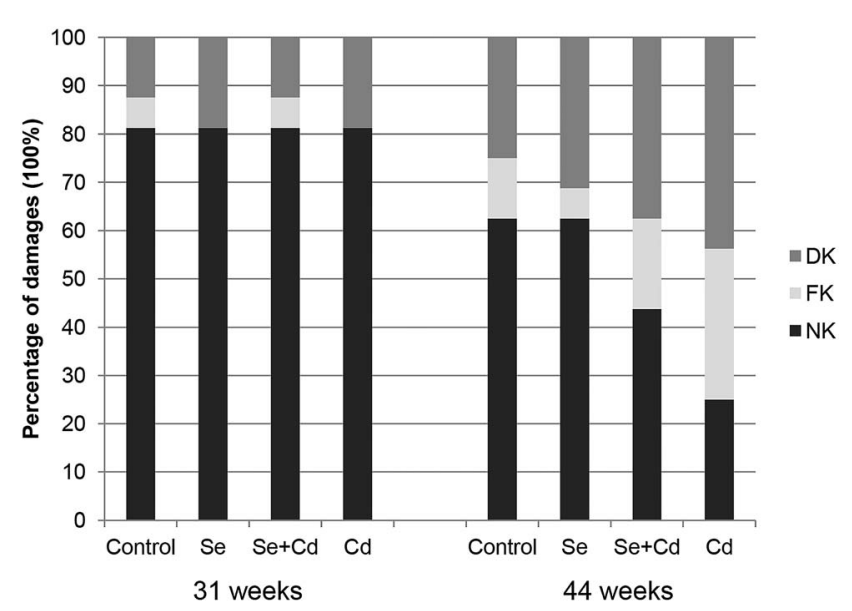

Fig. 1 Percentages of laying hens with fractured keel bones (FK) and deviated keel bones (DK) at the beginning and end of the experiments. Keel bones at 31 weeks of age were assessed by palpation and at 44 weeks were visually assessed after dissection. 
FK and DK in control group, Se treated group, Se + Cd treated group and $\mathrm{Cd}$ treated group were $12.5 \%$ and $25 \%, 6.25 \%$ and $31.25 \%, 18.75 \%$ and $37.5 \%, 31.25 \%$ and $43.75 \%$, respectively. After 13 weeks, the dietary Se supplementation alone did not change the alteration of the keel bone damage in comparison to laying hens in the control group. The percentages of FK and DK increased by $25 \%$ and $12.5 \%$ respectively in the Cd fed group, when compared to the laying hens in the control group. For the Se + Cd treated group, the FK and DK increased by $6.25 \%$ and $12.5 \%$ compared to the control group. However, treatment with both Se and Cd resulted in a decrease in FK of $18.75 \%$ compared to the Cd treatment.

Supplementation with $2 \mathrm{mg} \mathrm{kg}^{-1}$ of $\mathrm{Na}_{2} \mathrm{SeO}_{3}$ alone had no significant impact on the keel bone radiographic density of laying hens (Fig. 2). Exposure to Cd led to a marked decrease for $\mathrm{KBD}(P<0.05)$ compared to the control, Se treated and Se $+\mathrm{Cd}$ treated group, respectively. However, after Se and $\mathrm{Cd}$ coadministration, the KBD was lower compared to the control and Se treatment groups $(P<0.05)$, whereas bone density was higher than in the Cd treated group $(P<0.05)$.

\section{ALP activity and OC levels in serum}

As shown in Fig. 3, compared with control group, ALP activity had an increasing trend in Se, Se + Cd and Cd treated groups, but there were no significant differences among the treatments $(P>0.05)$. The OC levels in the Se and Se + Cd co-treatment groups increased slightly compared to the control $(P>0.05)$, whereas the concentrations of serum OC significantly decreased with the addition of $\mathrm{Cd}$ to the diet when compared to the other three treatments $(P<0.05)$.

\section{Concentrations of mineral elements in keel bone}

The concentrations of 28 mineral elements in keel bone are listed in Table 2. Neither dietary Se and Cd supplementation as singular factors, nor their combination had a significant effect on the contents of 15 elements, including $\mathrm{Li}, \mathrm{B}, \mathrm{Na}, \mathrm{Mg}, \mathrm{Ti}, \mathrm{V}$, $\mathrm{Fe}, \mathrm{Co}, \mathrm{As}, \mathrm{Sr}, \mathrm{Sn}, \mathrm{Sb}, \mathrm{Ba}, \mathrm{Hg}$, Tl $(P>0.05)$. Thirteen elements were observed to be significantly altered. Changes in there concentrations are summarized in Fig. 4. The addition of $150 \mathrm{mg} \mathrm{kg}{ }^{-1} \mathrm{CdCl}_{2}$ to the diet significantly increased the

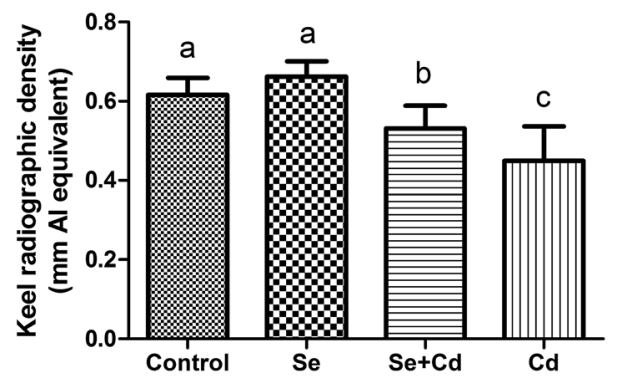

Fig. 2 The keel bone radiographic density of laying hens treated by supplemented $\mathrm{Se}, \mathrm{Cd}$ or $\mathrm{Se}+\mathrm{Cd}$. Data are presented as the mean \pm standard deviation. Bars without a shared common letter are significantly different $(P<0.05)$.
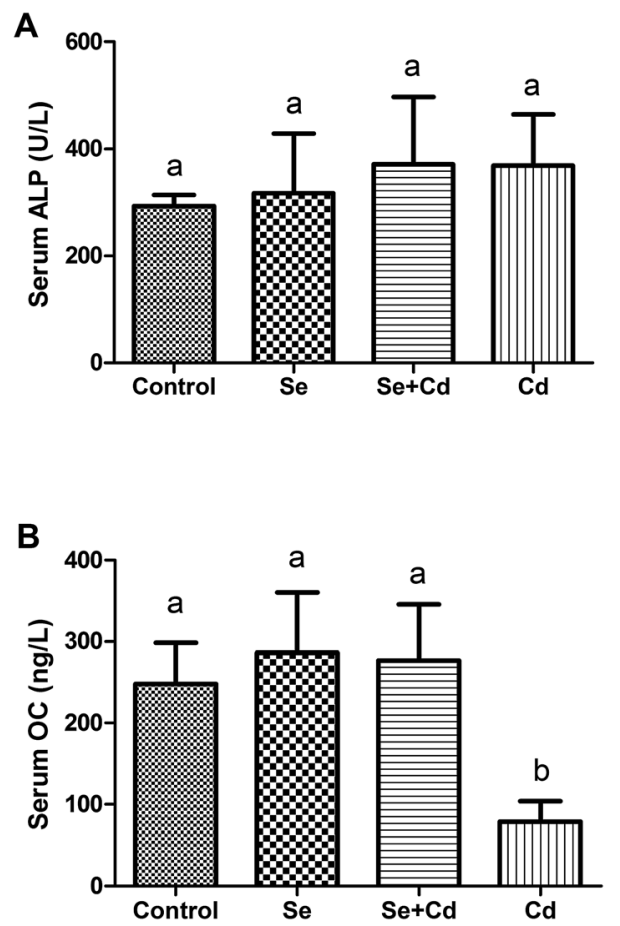

Fig. 3 The serum OC levels and ALP activity. $A=$ serum osteocalcin concentration $(\mathrm{OC}) ; \mathrm{B}=$ serum alkaline phosphatase concentration (ALP). All data are presented as the mean \pm standard deviation. Bars without a shared common letter are significantly different $(P<0.05)$.

concentrations of $\mathrm{Cd}$ and $\mathrm{Pb}(P<0.05)$, whereas the concentrations of $\mathrm{Si}, \mathrm{K}, \mathrm{Ca}, \mathrm{Cr}, \mathrm{Mn}, \mathrm{Cu}, \mathrm{Zn}$ and $\mathrm{Mo}$ in the bone significantly $(P<0.05)$ decreased compared to the control group. In the Se treated group, the concentrations of $\mathrm{Si}, \mathrm{Al}, \mathrm{Ni}$ and $\mathrm{Pb}$ were significantly $(P<0.05)$ decreased, and the concentrations of Se $(P<0.05)$ was significantly increased compared with the control. In $\mathrm{Se}+\mathrm{Cd}$ treated group, the compound treatment of $\mathrm{Se}$ and $\mathrm{Cd}$ resulted in reduced concentrations of Si, Al, Mn, Ni, $\mathrm{Zn}$ and Mo $(P<0.05)$ and improved concentrations of Se and $\mathrm{Cd}(P<0.05)$ when compared with those in the control group. Moreover, the $\mathrm{Se}+$ $\mathrm{Cd}$ co-treatment alleviated the degree of changes for the $\mathrm{K}, \mathrm{Ca}$, $\mathrm{Cr}, \mathrm{Cu}, \mathrm{Zn}, \mathrm{Cd}$ and $\mathrm{Pb}$ concentrations compared with the $\mathrm{Cd}$ treated group $(P<0.05)$. The $\mathrm{Cd}$ concentrations in the $\mathrm{Cd}$ treated group were as high as $2.64 \pm 0.18 \mathrm{mg} \mathrm{kg}^{-1}$ (approximately 250 times higher than the control). However, the concentrations of $\mathrm{Cd}$ in the Se $+\mathrm{Cd}$ treated group decreased by $33.36 \%$ compared with the Cd treated group.

Furthermore, the Cd concentrations of the serum collected from laying hens from the control group, Se treated group, Se $+\mathrm{Cd}$ treated group and Cd treated group were about $0.67 \pm$ $0.11,0.64 \pm 0.11,21.25 \pm 2.22$, and $34.74 \pm 2.89 \mu \mathrm{g} \mathrm{L}^{-1}$, respectively. The accumulation of $\mathrm{Cd}$ in keel bone was higher than that in the serum after the Cd treatment. The Se values were $86.07 \pm 6.17,252.26 \pm 23.46,151.48 \pm 14.65$, and 58.08 $\pm 7.14 \mu \mathrm{g} \mathrm{L}^{-1}$ in chicken serum from the control, Se treated, Se + Cd treated, and Cd treated groups, respectively. The concentrations of serum Se were decreased after the Cd exposure. 
Table 2 Effects of Se and Cd supplementation in the diet of laying hens on the concentration of 28 elements in keel bones ${ }^{a}$

\begin{tabular}{|c|c|c|c|c|c|}
\hline \multirow[b]{2}{*}{ Elements } & \multirow[b]{2}{*}{ Unit } & \multicolumn{4}{|l|}{ Treatment } \\
\hline & & Control & Se & $\mathrm{Se}+\mathrm{Cd}$ & $\mathrm{Cd}$ \\
\hline $\mathrm{B}$ & $\mathrm{mg} \mathrm{kg}^{-1}$ & $1.45 \pm 0.12^{\mathrm{a}}$ & $1.21 \pm 0.11^{\mathrm{a}}$ & $1.20 \pm 0.21^{\mathrm{a}}$ & $1.36 \pm 0.22^{\mathrm{a}}$ \\
\hline $\mathrm{Na}$ & $\mathrm{g} \mathrm{kg}^{-1}$ & $6.24 \pm 0.68^{\mathrm{a}}$ & $6.29 \pm 0.36^{\mathrm{a}}$ & $5.59 \pm 0.75^{\mathrm{a}}$ & $5.45 \pm 0.76^{\mathrm{a}}$ \\
\hline $\mathrm{Mg}$ & $\mathrm{g} \mathrm{kg}^{-1}$ & $2.89 \pm 0.38^{\mathrm{a}}$ & $2.80 \pm 0.27^{\mathrm{a}}$ & $2.79 \pm 0.31^{\mathrm{a}}$ & $2.67 \pm 0.43^{\mathrm{a}}$ \\
\hline $\mathrm{K}$ & $\mathrm{g} \mathrm{kg}^{-1}$ & $4.58 \pm 0.45^{\mathrm{a}}$ & $3.97 \pm 0.49^{\mathrm{ab}}$ & $3.98 \pm 0.20^{\mathrm{ab}}$ & $3.48 \pm 0.48^{\mathrm{b}}$ \\
\hline $\mathrm{Ca}$ & $\mathrm{g} \mathrm{kg}^{-1}$ & $271.15 \pm 23.28^{\mathrm{a}}$ & $275.19 \pm 24.74^{\mathrm{a}}$ & $252.88 \pm 15.50^{\mathrm{a}}$ & $181.43 \pm 28.67^{\mathrm{b}}$ \\
\hline $\mathrm{Ti}$ & $\mathrm{mg} \mathrm{kg}^{-1}$ & $879.11 \pm 57.89^{\mathrm{a}}$ & $832.81 \pm 106.64^{\mathrm{a}}$ & $794.16 \pm 81.90^{\mathrm{a}}$ & $822.87 \pm 100.02^{\mathrm{a}}$ \\
\hline $\mathrm{V}$ & $\mu \mathrm{g} \mathrm{kg}^{-1}$ & $675.04 \pm 84.82^{\mathrm{a}}$ & $679.67 \pm 96.32^{\mathrm{a}}$ & $582.18 \pm 87.28^{\mathrm{a}}$ & $616.66 \pm 168.40^{\mathrm{a}}$ \\
\hline $\mathrm{Cr}$ & $\mu \mathrm{g} \mathrm{kg}{ }^{-1}$ & $586.12 \pm 19.69^{\mathrm{a}}$ & $462.92 \pm 91.43^{\mathrm{a}}$ & $445.87 \pm 84.44^{\mathrm{a}}$ & $398.13 \pm 101.65^{b}$ \\
\hline Mn & $\mathrm{mg} \mathrm{kg}^{-1}$ & $28.59 \pm 2.45^{\mathrm{a}}$ & $25.45 \pm 4.76^{\mathrm{a}}$ & $15.54 \pm 2.72^{\mathrm{b}}$ & $15.38 \pm 2.70^{\mathrm{b}}$ \\
\hline $\mathrm{Zn}$ & $\mathrm{mg} \mathrm{kg}^{-1}$ & $228.51 \pm 12.35^{\mathrm{a}}$ & $243.92 \pm 32.36^{\mathrm{ab}}$ & $183.46 \pm 13.19^{\mathrm{c}}$ & $141.41 \pm 12.55^{\mathrm{d}}$ \\
\hline As & $\mu g \mathrm{~kg}^{-1}$ & $19.34 \pm 3.58^{\mathrm{a}}$ & $18.61 \pm 2.43^{\mathrm{a}}$ & $15.57 \pm 2.12^{\mathrm{a}}$ & $16.84 \pm 1.37^{\mathrm{a}}$ \\
\hline $\mathrm{Se}$ & $\mu \mathrm{g} \mathrm{kg} \mathrm{kg}^{-1}$ & $205.74 \pm 16.91^{\mathrm{a}}$ & $482.73 \pm 130.11^{\mathrm{b}}$ & $331.06 \pm 32.73^{\mathrm{c}}$ & $156.43 \pm 17.38^{\mathrm{a}}$ \\
\hline $\mathrm{Sr}$ & $\mathrm{mg} \mathrm{kg}^{-1}$ & $86.39 \pm 6.03^{\mathrm{a}}$ & $83.31 \pm 13.74^{\mathrm{a}}$ & $75.45 \pm 16.44^{\mathrm{a}}$ & $75.28 \pm 10.31^{\mathrm{a}}$ \\
\hline Mo & $\mu \mathrm{g} \mathrm{kg}^{-1}$ & $203.29 \pm 3.67^{\mathrm{a}}$ & $206.57 \pm 10.75^{\mathrm{a}}$ & $169.17 \pm 29.41^{\mathrm{b}}$ & $163.86 \pm 17.45^{\mathrm{b}}$ \\
\hline $\mathrm{Cd}$ & $\mu \mathrm{g} \mathrm{kg} \mathrm{kg}^{-1}$ & $10.64 \pm 3.37^{\mathrm{a}}$ & $10.56 \pm 2.29^{\mathrm{a}}$ & $1761.04 \pm 378.66^{\mathrm{b}}$ & $2642.71 \pm 184.75^{c}$ \\
\hline $\mathrm{Sn}$ & $\mu \mathrm{g} \mathrm{kg} \mathrm{kg}^{-1}$ & $39.46 \pm 2.87^{\mathrm{a}}$ & $37.31 \pm 5.65^{\mathrm{a}}$ & $39.15 \pm 1.46^{\mathrm{a}}$ & $34.96 \pm 4.85^{\mathrm{a}}$ \\
\hline $\mathrm{Sb}$ & $\mu \mathrm{g} \mathrm{kg}{ }^{-1}$ & $10.02 \pm 0.99^{\mathrm{a}}$ & $8.58 \pm 1.40^{\mathrm{a}}$ & $8.73 \pm 0.44^{\mathrm{a}}$ & $8.79 \pm 1.26^{\mathrm{a}}$ \\
\hline $\mathrm{Ba}$ & $\mathrm{mg} \mathrm{kg}^{-1}$ & $36.02 \pm 3.00^{\mathrm{a}}$ & $36.74 \pm 10.15^{\mathrm{a}}$ & $39.24 \pm 2.02^{\mathrm{a}}$ & $34.95 \pm 4.42^{\mathrm{a}}$ \\
\hline $\mathrm{Hg}$ & $\mu \mathrm{g} \mathrm{kg} \mathrm{kg}^{-1}$ & $0.55 \pm 0.15^{\mathrm{a}}$ & $0.64 \pm 0.15^{\mathrm{a}}$ & $0.70 \pm 0.20^{\mathrm{a}}$ & $0.56 \pm 0.17^{\mathrm{a}}$ \\
\hline $\mathrm{Tl}$ & $\mu \mathrm{g} \mathrm{kg} \mathrm{kg}^{-1}$ & $0.61 \pm 0.08^{\mathrm{a}}$ & $0.70 \pm 0.10^{\mathrm{a}}$ & $0.70 \pm 0.09^{\mathrm{a}}$ & $0.63 \pm 0.09^{\mathrm{a}}$ \\
\hline $\mathrm{Pb}$ & $\mathrm{mg} \mathrm{kg} \mathrm{kg}^{-1}$ & $1.56 \pm 0.23^{\mathrm{a}}$ & $1.04 \pm 0.18^{\mathrm{b}}$ & $1.67 \pm 0.13^{\mathrm{a}}$ & $2.46 \pm 0.32^{\mathrm{c}}$ \\
\hline
\end{tabular}

${ }^{a}$ Values are means $\pm \mathrm{SD}(n=8)$. The unit for the elements was micrograms per kilogram $\left(\mu \mathrm{g} \mathrm{kg}{ }^{-1}\right)$, milligrams per kilogram (mg kg $\left.{ }^{-1}\right)$, or grams per kilogram $\left(\mathrm{g} \mathrm{kg}^{-1}\right)$. Values with different letters within a row are significantly different $(P<0.05)$.

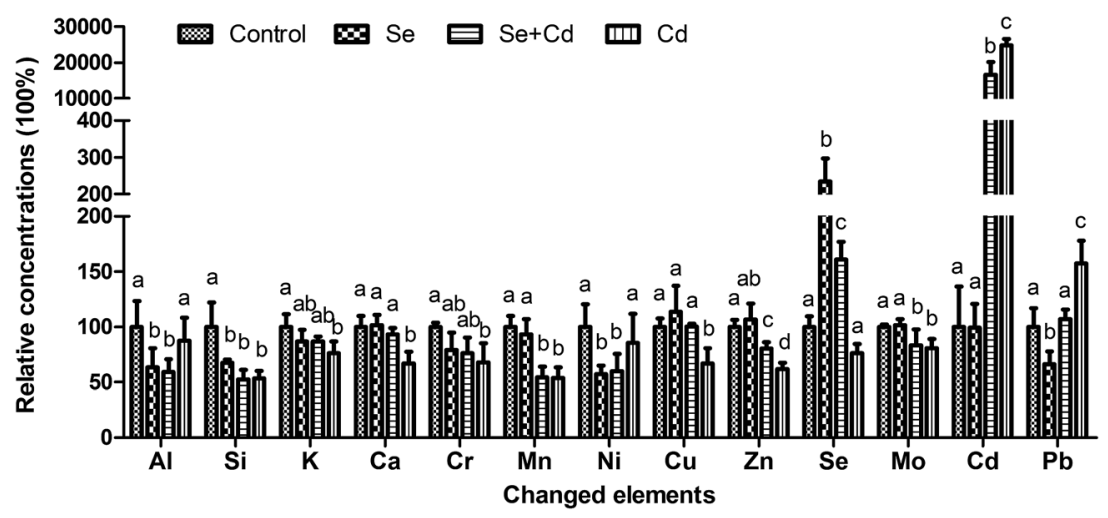

Fig. 4 Concentrations of mineral elements changed in the keel bone of laying hens affected by Se, Cd and Se $+\mathrm{Cd}$ co-treatment. Bars without a shared common letter are significantly different $(P<0.05)$. Data show the mean $\pm \operatorname{SD}(n=8)$.

\section{The correlation analysis}

The observed relationships among the parameters were confirmed and quantified according to the Spearman's correlation analysis (Table 3). The KBD had a positive correlation with the OC, Cd and $\mathrm{Pb}$ concentrations, while negative correlations were observed with $\mathrm{Si}, \mathrm{Ca}, \mathrm{Mn}$, and $\mathrm{Zn}$. The ALP activity was correlated negatively with $\mathrm{B}$ and $\mathrm{Fe}$. The OC content had a positive correlation with BMD, Cd and $\mathrm{Tl}$, and was negatively correlated with $\mathrm{Al}, \mathrm{Zn}$ and $\mathrm{Sb}$. In the descriptive statistics, the element Se was correlated positively with $\mathrm{Ca}, \mathrm{Cu}$ and $\mathrm{Zn}$ and negatively with $\mathrm{B}$ and $\mathrm{Al}$. It was observed that Cd was positively correlated with $\mathrm{Pb}$ and negatively with $\mathrm{Na}, \mathrm{Si}, \mathrm{Ca}$, $\mathrm{Mn}, \mathrm{Cu}, \mathrm{Zn}$, As, Se and Mo. Moreover, there were both positive and negative correlations between different pairs of elements not described here, which are reported in Table 3. 
Table 3 Correlations between the concentrations of 28 elements and KBD and serum biomarkers ${ }^{a}$

\begin{tabular}{|c|c|c|c|c|c|c|c|c|c|c|c|c|c|c|c|c|}
\hline & BMD & ALP & OC & $\mathrm{Li}$ & $\mathrm{B}$ & $\mathrm{Na}$ & $\mathrm{Mg}$ & $\mathrm{Al}$ & $\mathrm{Si}$ & K & $\mathrm{Ca}$ & $\mathrm{Ti}$ & $\mathrm{V}$ & $\mathrm{Cr}$ & $\mathrm{Mn}$ & $\mathrm{Fe}$ \\
\hline BMD & 1.00 & & & & & & & & & & & & & & & \\
\hline ALP & -0.31 & 1.00 & & & & & & & & & & & & & & \\
\hline $\mathrm{Li}$ & -0.33 & 0.01 & 0.24 & 1.00 & & & & & & & & & & & & \\
\hline $\mathrm{B}$ & -0.25 & $-0.53 *$ & -0.06 & $0.52^{*}$ & 1.00 & & & & & & & & & & & \\
\hline $\mathrm{Na}$ & -0.17 & 0.05 & 0.13 & 0.39 & 0.16 & 1.00 & & & & & & & & & & \\
\hline $\mathrm{Si}$ & $-0.59^{*}$ & 0.07 & -0.14 & 0.37 & 0.41 & $0.62^{*}$ & 0.11 & 0.39 & 1.00 & & & & & & & \\
\hline $\mathrm{K}$ & -0.08 & 0.19 & 0.10 & 0.09 & 0.22 & 0.20 & 0.13 & 0.12 & $0.51 *$ & 1.00 & & & & & & \\
\hline $\mathrm{Ca}$ & $-0.61 * *$ & 0.09 & 0.02 & 0.19 & 0.14 & 0.21 & -0.15 & -0.11 & $0.60^{*}$ & $0.51^{*}$ & 1.00 & & & & & \\
\hline $\mathrm{Ti}$ & -0.21 & 0.02 & 0.28 & 0.43 & $0.54^{*}$ & $0.52^{*}$ & 0.26 & 0.27 & $0.52^{*}$ & -0.07 & 0.19 & 1.00 & & & & \\
\hline $\mathrm{V}$ & -0.38 & 0.29 & -0.10 & $0.65^{* *}$ & 0.10 & 0.48 & 0.07 & $0.55^{*}$ & $0.63 * *$ & 0.17 & 0.33 & 0.41 & 1.00 & & & \\
\hline $\mathrm{Cr}$ & 0.36 & -0.36 & -0.13 & -0.06 & 0.43 & 0.17 & -0.20 & 0.14 & $0.68 * *$ & 0.49 & 0.41 & 0.30 & 0.10 & 1.00 & & \\
\hline $\mathrm{Cu}$ & -0.08 & 0.12 & 0.29 & 0.09 & -0.32 & $0.58^{*}$ & 0.26 & -0.36 & 0.30 & 0.03 & 0.30 & 0.13 & 0.12 & 0.06 & 0.30 & 0.11 \\
\hline $\mathrm{Zn}$ & $-0.71 * *$ & -0.07 & $-0.57^{*}$ & 0.13 & 0.06 & 0.41 & 0.04 & -0.02 & $0.67 * *$ & 0.34 & $0.78^{* * *}$ & 0.11 & 0.34 & 0.39 & $0.82^{* *}$ & 0.24 \\
\hline As & -0.27 & 0.11 & -0.15 & $0.62 *$ & 0.34 & $0.75^{* *}$ & 0.39 & 0.30 & $0.58^{*}$ & 0.18 & 0.14 & 0.41 & $0.67 * *$ & 0.06 & $0.497^{*}$ & 0.21 \\
\hline $\mathrm{Se}$ & $-0.55^{*}$ & -0.01 & 0.16 & -0.01 & $-0.50 *$ & 0.44 & 0.04 & $-0.59 *$ & 0.17 & -0.01 & 0.42 & -0.07 & 0.16 & 0.02 & 0.29 & 0.18 \\
\hline $\mathrm{Sr}$ & -0.29 & 0.03 & 0.06 & $0.77^{* *}$ & 0.34 & $0.69^{* *}$ & 0.20 & 0.37 & $0.60^{*}$ & 0.06 & 0.24 & $0.63^{* *}$ & $0.75^{* *}$ & 0.15 & $0.56^{*}$ & 0.34 \\
\hline Mo & -0.18 & 0.06 & -0.25 & 0.44 & 0.20 & $0.66^{* *}$ & 0.11 & 0.32 & $0.70^{* *}$ & 0.21 & 0.46 & 0.40 & $0.60^{*}$ & 0.18 & $0.71 * *$ & 0.24 \\
\hline $\mathrm{Cd}$ & $0.57^{*}$ & -0.09 & 0.30 & -0.14 & 0.05 & $-0.63^{*}$ & -0.17 & -0.06 & -0.77 & -0.44 & $-0.60^{*}$ & -0.07 & -0.49 & -0.39 & $-0.76^{* *}$ & -0.10 \\
\hline Sn & 0.16 & -0.18 & 0.07 & 0.15 & -0.02 & 0.12 & 0.16 & -0.01 & 0.06 & -0.19 & -0.14 & -0.09 & -0.13 & 0.12 & 0.06 & 0.15 \\
\hline $\mathrm{Sb}$ & 0.14 & -0.23 & $-0.58^{*}$ & 0.19 & 0.26 & 0.21 & 0.28 & $0.54^{*}$ & 0.36 & 0.03 & -0.11 & -0.01 & 0.18 & 0.29 & 0.41 & 0.23 \\
\hline $\mathrm{Ba}$ & 0.07 & -0.11 & 0.20 & 0.34 & -0.15 & 0.16 & 0.12 & 0.12 & 0.01 & -0.17 & -0.10 & 0.18 & 0.34 & -0.01 & 0.18 & 0.45 \\
\hline $\mathrm{Hg}$ & -0.23 & -0.29 & -0.04 & -0.09 & -0.24 & 0.45 & 0.29 & -0.36 & -0.14 & -0.22 & -0.26 & 0.02 & -0.03 & -0.17 & -0.10 & 0.34 \\
\hline $\mathrm{Tl}$ & 0.03 & -0.14 & $0.54^{*}$ & 0.18 & -0.17 & 0.44 & 0.34 & -0.38 & -0.14 & -0.28 & -0.28 & 0.08 & -0.14 & -0.23 & 0.00 & $0.52 *$ \\
\hline
\end{tabular}

\begin{tabular}{|c|c|c|c|c|c|c|c|c|c|c|c|c|c|c|}
\hline Co & 1.00 & & & & & & & & & & & & & \\
\hline $\mathrm{Ni}$ & 0.09 & 1.00 & & & & & & & & & & & & \\
\hline $\mathrm{Zn}$ & -0.06 & -0.07 & 0.47 & 1.00 & & & & & & & & & & \\
\hline $\mathrm{Se}$ & 0.15 & -0.46 & $0.82 * *$ & $0.56^{*}$ & 0.08 & 1.00 & & & & & & & & \\
\hline $\mathrm{Sr}$ & 0.03 & -0.05 & 0.44 & 0.33 & $0.73^{* *}$ & 0.27 & 1.00 & & & & & & & \\
\hline Mo & -0.25 & -0.01 & $0.55^{*}$ & $0.67^{*}$ & $0.59 *$ & 0.38 & $0.75^{* *}$ & 1.00 & & & & & & \\
\hline $\mathrm{Sb}$ & 0.18 & $0.55^{*}$ & 0.07 & 0.24 & 0.29 & -0.18 & 0.29 & 0.27 & -0.33 & $0.59^{*}$ & 1.00 & & & \\
\hline $\mathrm{Ba}$ & $0.60^{*}$ & 0.00 & 0.39 & 0.07 & 0.05 & 0.36 & $0.56^{*}$ & 0.22 & -0.09 & 0.42 & 0.29 & 1.00 & & \\
\hline $\mathrm{Hg}$ & -0.09 & -0.40 & 0.40 & 0.09 & 0.23 & $0.51^{*}$ & 0.21 & 0.20 & -0.24 & 0.12 & -0.10 & 0.31 & 1.00 & \\
\hline $\mathrm{Tl}$ & 0.29 & -0.35 & $0.70 * *$ & -0.01 & 0.05 & $0.54^{*}$ & 0.33 & 0.18 & -0.06 & $0.55^{*}$ & 0.09 & $0.54^{*}$ & $0.52 *$ & 1.00 \\
\hline $\mathrm{Pb}$ & 0.27 & 0.47 & $-0.64^{*}$ & $-0.76^{* *}$ & -0.41 & $-0.74^{* *}$ & -0.36 & $-0.62^{*}$ & $0.76 * *$ & -0.07 & 0.16 & 0.13 & -0.28 & -0.18 \\
\hline
\end{tabular}

${ }^{a}$ Level of statistical significance: $* P<0.05 ; * * P<0.01$.

\section{Discussion}

The present paper investigated the hypothesis that enhanced Se intake during exposure to $\mathrm{Cd}$ in laying hens may have a protective effect against keel bone damage. As expected, the percentages of FK and DK increased by 25\% and $12.5 \%$ respectively as a result of Cd toxicity when compared to the control group. The increased bone damage was also manifested in the reduction of BMD in the Cd treated laying hens. Brzoska et al. found that the exposure to Cd was dose and time dependently influenced the tibia BMD and chemical composition, and the decrease in BMD enhanced the risk of tibia fracture. ${ }^{36}$ Exposure to 5 and $50 \mathrm{mg} \mathrm{L}^{-1} \mathrm{Cd}$ for 12 months, or $1 \mathrm{mg} \mathrm{L}^{-1} \mathrm{Cd}$ for 24 months resulted in a profound decrease in the femur and lumbar vertebral BMD, making the bones more susceptible to fracture..$^{13,37,38}$ Considering the previous observations, high rates 
of bone damage caused by $\mathrm{Cd}$ may be explained by its toxic actions against the bone organic and non-organic phases. $\mathrm{Cd}$ directly influences the differentiation and activity of osteoblastic and osteoclastic cells as well as interferes with hydroxyapatite formation, leading to the increased bone resorption and bone mineral dissolution. ${ }^{7,37-39}$ Se plays a major role in cellular redox status and an important regulatory role for normal bone metabolism..$^{\mathbf{2 0 , 4 0}}$ It has been reported that selenium deficient young male rats had low BMD, osteopenia and growth retardation. ${ }^{\mathbf{4 1}}$ Studies in mice indicated that Se deficiency increased bone resorption and had detrimental effects on bone microarchitecture resulting from decreasing antioxidative potential. $^{42}$ The study revealed a positive trend to increase the BMD upon supplementation of $2 \mathrm{mg} \mathrm{kg}^{-1}$ of $\mathrm{Na}_{2} \mathrm{SeO}_{3}$. For Se and Cd co-treated hens, the percentage of $\mathrm{KF}$ decreased and the BMD increased $(P<0.05)$ when compared to that of the Cd treated group. Thus, supplementation with Se partially prevented the Cd induced KBD to laying hens at the time of peak lay. The positive influences on the bone health of Se at both nutritional and supranutritional doses may be consisted in its ability to overcome the inhibition of osteoblast activity and the acceleration of bone resorption caused by $\mathrm{Cd}$ exposure.

The ALP activity and the concentrations of OC in serum have been used as biomarkers of osteoblast activity for the evaluation of bone remolding. ${ }^{43}$ In this study, ALP activity was not significantly altered for any treatment. The OC levels increased in both of the Se and Se + Cd treated groups, but the addition of Cd significantly decreased the levels of serum OC $(P<0.05)$. These results reflect the inhibitory effect of $\mathrm{Cd}$ on the degree of bone mineralization and the processes of bone formation, despite unchanged ALP activity in the keel bone. This inhibition of Cd toxicity was ameliorated by Se. Similarly, Brzoska et al. reported that rats exposed to 5 and $50 \mathrm{mg} \mathrm{L}^{-1} \mathrm{Cd}$ resulted in a decrease in serum OC concentration as well as bone ALP activities, however, the serum ALP was not detected. ${ }^{39}$

The antagonistic effects of Se on Cd via Cd accumulation in poultry have been reported in previous studies. Pappas et al. reported that chicks fed with a basal diet (containing $0.21 \mathrm{mg}$ $\mathrm{kg}^{-1} \mathrm{Se}$ ) with additional $0.15,0.3$ and $3.0 \mathrm{mg} \mathrm{kg}^{-1}$ Se not only increased Se concentration but also reduced Cd concentration in the liver, blood and muscle tissues. ${ }^{25}$ It was reported that in hens and cocks fed $20 \mathrm{mg} \mathrm{kg}^{-1} \mathrm{Cd}$ or $30 \mathrm{mg} \mathrm{kg}^{-1} \mathrm{Cd}+4 \mathrm{mg} \mathrm{kg}^{-1}$ Se for 8 weeks, the Cd levels were substantially increased in the liver and kidneys, and supplementation with Se resulted in Cd reduction. ${ }^{44}$ The present study revealed that sub-chronic Cd exposure could lead to massive accumulation of $\mathrm{Cd}$ in the keel bone. The Cd levels in the $\mathrm{Cd}$ treated group reached up to $2.64 \mathrm{mg} \mathrm{kg}^{-1}$, almost 250 times as much as in the control and the Se treated groups. The $\mathrm{Cd}$ content in the $\mathrm{Se}+\mathrm{Cd}$ treated group decreased by $33.36 \%$ compared with the $\mathrm{Cd}$ treated group. Simultaneously, Se concentrations in the Se $+\mathrm{Cd}$ group were lower than the Se treated group, and higher than the control and Cd treated groups. These results indicate that the concentrations of Cd were significantly decreased when the Se was co-administered with $\mathrm{Cd}$, accompanied with the dissolution of Se from the keel bone. As we all know, metallothioneins
(MT) are rich in cysteine which confers these proteins with a high capacity to bind heavy mental elements, such as $\mathrm{Zn}, \mathrm{Cu}$, $\mathrm{Cd}$, and $\mathrm{Hg}$, etc. in biological systems. ${ }^{45}$ When the contents of $\mathrm{Cd}$ in the body exceed the binding capacity of MT, the non-MT bound Cd ions lead toxicity to liver, kidney and bones possibly due to induction of oxidative stress, inhibition of gene repair and deregulation of cell multiplication. ${ }^{46}$ The concentrations of Se in the Se $+\mathrm{Cd}$ treated group were lower than the Se treated group and the deposition of $\mathrm{Cd}$ in Se and Cd co-treatment lower than $\mathrm{Cd}$ treated alone, the possible reason is that the formation of Se-Cd complexes or consumption of protecting against the Cd-induced cellular toxicity. ${ }^{24,47}$ Controversially, previous work on the well-established protective effect of Se and $\mathrm{Zn}$ against $\mathrm{Cd}$ induced toxicity was more dependent on the oxidative stress decreasing than through the MT gene expression mechanisms. ${ }^{48}$ However, Se administered at supranutritional doses was unable to completely ameliorate the toxic effects of $\mathrm{Cd}$ in bones.

The Cd exposure influenced the normal homeostasis of many elements. Brzoska et al. demonstrated that $50 \mu \mathrm{g} \mathrm{mL}{ }^{-1} \mathrm{Cd}$ added to water for 12 weeks decreased the $\mathrm{Ca}, \mathrm{Zn}$, and $\mathrm{Fe}$ contents in the tibia, but had no effect on the $\mathrm{Mg}$ or $\mathrm{Cu}$ contents. ${ }^{49}$ Another study by the same researchers revealed that when $50 \mathrm{mg} \mathrm{L}^{-1} \mathrm{Cd}$ was added to the water, decreases in $\mathrm{Ca}, \mathrm{P}$, $\mathrm{Zn}, \mathrm{Mg}, \mathrm{Cu}$ and Fe contents were observed in the lumbar spine of rats. ${ }^{16}$ It was reported that in ducks fed a commercial diet containing Cd for 120 days, the metatarsal bones were damaged via disturbances in the systemic balance of $\mathrm{Ca}$ and $\mathrm{P}$ in body and homeostasis of $\mathrm{Se}, \mathrm{Zn}, \mathrm{Cu}$ and Fe in bones. ${ }^{50}$ Moreover, the addition of $\mathrm{Cd}$ to the diets of quails resulted in a quadratic increase in Cd concentrations and a decrease in B concentrations in the tibia. ${ }^{51}$ Changes in the levels of mineral elements and their compositions in any organ or tissue, as a consequence, can increase the risk of damages to the body. ${ }^{52}$ In the present study, the levels of 28 elements were analyzed in the keel bone of laying hens treated with a Se, Cd, or Se + Cd supplemented diet. The Cd treatment caused metabolic disorders of 10 mineral elements, significantly $(P<0.05)$ reducing the concentrations of $\mathrm{Si}, \mathrm{K}, \mathrm{Ca}, \mathrm{Cr}, \mathrm{Mn}, \mathrm{Cu}, \mathrm{Zn}$ and $\mathrm{Mo}$, with increases in $\mathrm{Cd}$ and $\mathrm{Pb}$ concentrations in comparison to the control group. The homeostasis of mineral elements is necessary for catalyzing enzymatic activity, maintaining structural integrity, and various other biological processes. ${ }^{53}$ Therefore, it is possible that enzymatic reaction, signal transduction, biological activators and/or inhibitors, and antioxidant system were abnormal due to imbalances of the aforementioned elements caused by the toxic effects of Cd. Furthermore, it was demonstrated here that Se supplementation alone affected the ion profiles reducing the concentrations of $\mathrm{Si}, \mathrm{Al}, \mathrm{Ni}$ and $\mathrm{Pb}$, while obviously improving the levels of Se. What's more, cotreatment with Se and Cd alleviated the degree of changes for the $\mathrm{K}, \mathrm{Ca}, \mathrm{Cr}, \mathrm{Cu}, \mathrm{Zn}, \mathrm{Cd}$ and $\mathrm{Pb}$ concentrations compared with the $\mathrm{Cd}$ treated group $(P<0.05)$. It is well known that in addition to passive roles as a substrate for bone formation, the element Ca plays the main active role in bone metabolism. Whereas the other macro elements ( $\mathrm{K}, \mathrm{Na}$, and $\mathrm{Mg}$ ) and some of the discovered essential trace elements (e.g., $\mathrm{Cu}, \mathrm{Mn}, \mathrm{Zn}, \mathrm{Se}, \mathrm{F}, \mathrm{Fe}$, 
$\mathrm{Cr}$ and B) have protective effects, others are toxic microelements (e.g., $\mathrm{Cd}$ and $\mathrm{Al}$ ) having detrimental effects on bone health. ${ }^{54}$ Due to the hazardous effects of essential element deficiencies and toxic trace element accumulation, the protective effects of Se against the toxicity of $\mathrm{Cd}$ might result from the maintenance of homeostasis of elements $\mathrm{K}, \mathrm{Ca}, \mathrm{Cr}, \mathrm{Cu}, \mathrm{Zn}, \mathrm{Cd}$ and $\mathrm{Pb}$ in the keel bone. $\mathrm{K}$ may help prevent osteoporosis by preserving $\mathrm{Ca}$ in bones and maintaining normal $\mathrm{PH}$. It has shown an improved $\mathrm{Ca}$ balance, decreased bone resorption and increased bone formation with the K supplementation. ${ }^{55,56}$ The bone mineral phase is composed mainly of Ca forming hydroxyapatite crystals and the direct toxicity of $\mathrm{Cd}$ is interfering $\mathrm{Ca}^{2+}$ in the process of incorporation into hydroxyapatites. ${ }^{57,58}$ It has been demonstrated that time-course of Ca release from bone after $\mathrm{Cd}$ exposure, which leads to higher bone loss, lower BMD, and negative Ca balance. ${ }^{59}$ $\mathrm{Zn}$, occurring in the active centers of many enzymes such as alkaline phosphatase or carbonic anhydrase, is responsible for the bone metabolism and matrix formation with the procession of stimulating the synthesis of DNA in osteoblasts and increasing the concentrations of $\mathrm{Ca}$ ions. ${ }^{\mathbf{6 0 , 6 1}}$ This bio-element deficiency leads to a reduction in osteoblastic activity and collagen synthesis. ${ }^{62} \mathrm{Cu}$, similar to $\mathrm{Zn}$, functions as a general enzymatic cofactor. By activating lysyl oxidase, it induces the formation of lysine crosslinks in collagen and elastin. ${ }^{63} \mathrm{Cr}$, as a cofactor of insulin, is known to alleviate the detrimental effects of stress in chickens by augmenting antioxidant defense and reducing lipid peroxidation. ${ }^{64}$ It has been demonstrated that bones contain approximately $90 \%$ of the total amount of $\mathrm{Pb}$ in the body. $\mathrm{Pb}$ accumulation in bones can increase of excretion of $\mathrm{Ca}$ and decrease the BMD. ${ }^{65}$ In previous study, $\mathrm{Pb}$ supplementation with diets could increase the concentrations of $\mathrm{Cd}$ in chicken liver. ${ }^{66}$ Herein, Cd exposure increased the concentrations of $\mathrm{Pb}$ in keel bones. We speculate that these two toxic elements may have synergistic effect to the body.

This study indicated both negative and positive correlations among the parameters and different elements. The BMD was positively correlated with $\mathrm{OC}, \mathrm{Cd}$ and $\mathrm{Pb}$, which had negative effects on bone health. The analysis revealed that the keel BMD and OC levels in hens co-treatment with $\mathrm{Cd}$ and Se were primarily affected by Cd. Similarly, Brzoska et al. showed that when the rats were co-administered $\mathrm{Zn}$ and $\mathrm{Cd}$, the $\mathrm{Cd}$ toxicity played the major role in influencing the femoral BMD and serum OC. ${ }^{39}$ The element Se was positively correlated with $\mathrm{Ca}, \mathrm{Cu}$ and $\mathrm{Zn}$, whereas, $\mathrm{Cd}$ was correlated negatively with $\mathrm{Na}, \mathrm{Si}, \mathrm{Ca}, \mathrm{Mn}, \mathrm{Cu}, \mathrm{Zn}, \mathrm{As}$, Se and Mo. The previous study on interactions between 15 elements possessing antioxidant effects was analyzed after the chickens supplemented with the $\mathrm{Cd}$ and organic Se, which revealed that $\mathrm{Cd}$ was correlated with $\mathrm{Ca}, \mathrm{Co}, \mathrm{Cu}$ and $\mathrm{Mg}$, while Se was correlated with $\mathrm{Mn}^{.24}$ Thus, the alterations in the levels of mineral elements were sufficiently complicated by the Se and Cd treatment, making it difficult to distinguish which element or which interaction played the primary or secondary effect.

\section{Conclusions}

The current study suggests that the diets of laying hens supplemented with Se can, at least in part, prevent KBD induced by the relatively high sub-chronic exposure to Cd. Supplementation with Se counteracted the reduced keel BMD and reduced the risk of keel bone fractures caused by the Cd toxicity. The antagonistic effects of Se may be aided by its ability to inhibit Cd accumulation and by protecting the homeostasis of elements that are disturbed by exposure to $\mathrm{Cd}$.

\section{Conflict of interest}

The authors declare that they have no conflicts of interest.

\section{Acknowledgements}

This study was supported by the National Natural Science Foundation of China (31501992, 31672466), the China Postdoctoral Science Foundation (Grant No. 2016M591505), and the Heilongjiang Postdoctoral Fund (Grant No. LBH-Z14223). All authors read and approved the final manuscript.

\section{References}

1 A. Rani, A. Kumar, A. Lal and M. Pant, Int. J. Environ. Health Res., 2014, 24, 378-399.

2 L. Jarup, Nephrol., Dial., Transplant., 2002, 17(2), 35-39.

3 G. F. Nordberg, Toxicol. Appl. Pharmacol., 2009, 238, 192-200.

4 M. Sughis, J. Penders, V. Haufroid, B. Nemery and T. S. Nawrot, Environ. Health, 2011, 10, 104.

5 R. Schutte, T. S. Nawrot, T. Richart, L. Thijs, D. Vanderschueren, T. Kuznetsova, E. Van Hecke, H. A. Roels and J. A. Staessen, Environ. Health Perspect., 2008, 116, 777-783.

6 T. Alfven, C. G. Elinder, L. Hellstrom, F. Lagarde and L. Jarup, J. Bone Miner. Res., 2004, 19, 900-905.

7 X. Chen, G. Zhu, T. Jin, L. Lei and Y. Liang, Environ. Toxicol. Pharmacol., 2011, 32, 46-53.

8 M. M. Brzoska and J. Moniuszko-Jakoniuk, Arch. Toxicol., 1998, 72, 63-73.

9 L. Sun, Y. Yu, T. Huang, P. An, D. Yu, Z. Yu, H. Li, H. Sheng, L. Cai, J. Xue, M. Jing, Y. Li, X. Lin and F. Wang, PLoS One, 2012, 7, e38845.

10 H. D. Yao, Q. Wu, Z. W. Zhang, J. L. Zhang, S. Li, J. Q. Huang, F. Z. Ren, S. W. Xu, X. L. Wang and X. G. Lei, J. Nutr., 2013, 143, 613-619.

11 J. Rodriguez and P. M. Mandalunis, Exp. Toxicol. Pathol., 2016, 68, 391-397.

12 M. M. Brzoska, K. Majewska and E. Kupraszewicz, Environ. Toxicol. Pharmacol., 2010, 29, 235-245.

13 M. M. Brzoska and J. Moniuszko-Jakoniuk, Toxicol. Appl. Pharmacol., 2005, 207, 195-211.

14 M. M. Brzoska, K. Majewska and J. Moniuszko-Jakoniuk, Bone, 2004, 34, 517-526.

15 M. M. Brzoska, J. Moniuszko-Jakoniuk, M. Jurczuk and M. Galazyn-Sidorczuk, Alcohol Alcohol., 2002, 37, 213-221.

16 M. M. Brzoska and J. Moniuszko-Jakoniuk, Toxicol. Lett., 2005, 157, 161-172.

17 M. M. Brzoska, J. Appl. Toxicol., 2012, 32, 34-44.

18 C. Liu, J. Fu, C. Liu and S. Li, RSC Adv., 2015, 5, 50549-50556. 
19 H. D. Yao, Q. Wu, Z. W. Zhang, S. Li, X. L. Wang, X. G. Lei and S. W. Xu, Biochim. Biophys. Acta, 2013, 1830, 3112-3120.

20 Z. Zhang, J. Zhang and J. Xiao, Biochim. Biophys. Acta, 2014, 1840, 3246-3256.

21 H. Zeng, J. J. Cao and G. J. Combs, Nutrients, 2013, 5, 97-110.

22 L. L. Liu, C. M. Li, Z. W. Zhang, J. L. Zhang, H. D. Yao and S. W. Xu, Biol. Trace Elem. Res., 2014, 158, 176-185.

23 M. Lazarus, T. Orct, J. Jurasoviae and M. Blanusa, BioMetals, 2009, 22, 973-983.

24 A. Al-Waeli, A. C. Pappas, E. Zoidis, C. A. Georgiou, K. Fegeros and G. Zervas, Br. Poult. Sci., 2012, 53, 817-827.

25 A. C. Pappas, E. Zoidis, C. A. Georgiou, N. Demiris, P. F. Surai and K. Fegeros, Food Addit. Contam., Part A: Chem., Anal., Control, Exposure Risk Assess., 2011, 28, 446-454.

26 R. Zhang, Y. Wang, C. Wang, P. Zhao, H. Liu, J. Li and J. Bao, Biol. Trace Elem. Res., 2016, DOI: 10.1007/s12011-016-0825-x.

27 S. Kappeli, S. G. Gebhardt-Henrich, E. Frohlich, A. Pfulg and M. H. Stoffel, Br. Poult. Sci., 2011, 52, 531-536.

28 R. H. Fleming, H. A. McCormack, L. McTeir and C. C. Whitehead, Br. Poult. Sci., 2004, 45, 320-330.

29 P. Y. Hester, S. A. Enneking, B. K. Haley, H. W. Cheng, M. E. Einstein and D. A. Rubin, Poult. Sci., 2013, 92, 19721980.

30 A. Harlander-Matauschek, T. B. Rodenburg, V. Sandilands, B. W. Tobalske and M. J. Toscano, World's Poult. Sci. J., 2015, 71, 461-472.

31 R. Zhang, L. Wang, J. Zhao, C. Wang, J. Bao and J. Li, Biol. Trace Elem. Res., 2016, 174, 218-225.

32 L. J. Wilkins, S. N. Brown, P. H. Zimmerman, C. Leeb and C. J. Nicol, Vet. Rec., 2004, 155, 547-549.

33 B. Scholz, S. Ronchen, H. Hamann, M. Hewicker-Trautwein and O. Distl, Berliner und Münchener tierärztliche Wochenschrift, 2008, 121, 89-94.

34 T. Casey-Trott, J. L. Heerkens, M. Petrik, P. Regmi, L. Schrader, M. J. Toscano and T. Widowski, Poult. Sci., 2015, 94, 2339-2350.

35 S. Jiang, L. Cui, C. Shi, X. Ke, J. Luo and J. Hou, Vet. J., 2013, 198, 252-258.

36 M. M. Brzoska, K. Majewska and J. Moniuszko-Jakoniuk, Food Chem. Toxicol., 2005, 43, 1507-1519.

37 M. M. Brzoska and J. Moniuszko-Jakoniuk, Toxicol. Appl. Pharmacol., 2005, 202, 68-83.

38 M. M. Brzoska and J. Moniuszko-Jakoniuk, Bone, 2004, 35, 1180-1191.

39 M. M. Brzoska, J. Rogalska, M. Galazyn-Sidorczuk, M. Jurczuk, A. Roszczenko, E. Kulikowska-Karpinska and J. Moniuszko-Jakoniuk, Toxicology, 2007, 237, 89-103.

40 Z. Zhang, M. Bi, Q. Liu, J. Yang and S. Xu, Oncotarget, 2016, 7, 77110-77116.

41 R. Moreno-Reyes, D. Egrise, J. Neve, J. L. Pasteels and A. Schoutens, J. Bone Miner. Res., 2001, 16, 1556-1563.
42 J. J. Cao, B. R. Gregoire and H. Zeng, J. Nutr., 2012, 142, 15261531.

43 M. J. Seibel, Clin. Biochem. Rev., 2005, 26, 97-122.

44 E. Marettova, M. Maretta, J. Legath and E. Kosutzka, Biol. Trace Elem. Res., 2012, 147, 130-134.

45 F. Dondero, L. Piacentini, M. Banni, M. Rebelo, B. Burlando and A. Viarengo, Gene, 2005, 345, 259-270.

46 D. Beyersmann and A. Hartwig, Arch. Toxicol., 2008, 82, 493512.

47 A. S. El-Sharaky, A. A. Newairy, M. M. Badreldeen, S. M. Eweda and S. A. Sheweita, Toxicology, 2007, 235, 185193.

48 M. Banni, I. Messaoudi, L. Said, H. J. El, A. Kerkeni and K. Said, Arch. Environ. Contam. Toxicol., 2010, 59, 513-519.

49 M. M. Brzoska, J. Moniuszko-Jakoniuk, M. Jurczuk, M. Galazyn-Sidorczuk and J. Rogalska, Food Chem. Toxicol., 2001, 39, 729-737.

50 Y. Liao, H. Cao, B. Xia, Q. Xiao, P. Liu, G. Hu and C. Zhang, Biol. Trace Elem. Res., 2017, 175, 449-457.

51 O. Olgun, Animal, 2015, 9, 1298-1303.

52 C. Palacios, Crit. Rev. Food Sci. Nutr., 2006, 46, 621-628.

53 K. D. Cashman, Int. Dairy J., 2006, 16, 1389-1398.

54 I. Zofkova, P. Nemcikova and P. Matucha, Clin. Chem. Lab. Med., 2013, 51, 1555-1561.

55 S. A. New, S. P. Robins, M. K. Campbell, J. C. Martin, M. J. Garton, C. Bolton-Smith, D. A. Grubb, S. J. Lee and D. M. Reid, Am. J. Clin. Nutr., 2000, 71, 142-151.

56 J. J. Lemann, J. A. Pleuss and R. W. Gray, J. Nutr., 1993, 123, 1623-1626.

57 N. C. Blumenthal, V. Cosma, D. Skyler, J. LeGeros and M. Walters, Calcif. Tissue Int., 1995, 56, 316-322.

58 K. Iwami and T. Moriyama, Arch. Toxicol., 1993, 67, 352-357.

59 M. H. Bhattacharyya, Toxicol. Appl. Pharmacol., 2009, 238, 258-265.

60 A. G. Scrimgeour, C. H. Stahl, J. P. McClung, L. J. Marchitelli and A. J. Young, J. Nutr. Biochem., 2007, 18, 813-819.

61 Z. J. Ma and M. Yamaguchi, J. Bone Miner. Metab., 2000, 18, 264-270.

62 K. B. Hadley, S. M. Newman and J. R. Hunt, J. Nutr. Biochem., 2010, 21, 297-303.

63 R. B. Rucker, T. Kosonen, M. S. Clegg, A. E. Mitchell, B. R. Rucker, J. Y. Uriu-Hare and C. L. Keen, Am. J. Clin. Nutr., 1998, 67, 996S-1002S.

64 S. V. Rao, M. V. Raju, A. K. Panda, N. S. Poonam, O. K. Murthy and G. S. Sunder, Biol. Trace Elem. Res., 2012, 147, 135-141.

65 K. Theppeang, T. A. Glass, K. Bandeen-Roche, A. C. Todd, C. A. Rohde, J. M. Links and B. S. Schwartz, Environ. Health Perspect., 2008, 116, 784-790.

66 T. Xu, X. Gao and G. Liu, Biol. Trace Elem. Res., 2016, 169, 365-373. 